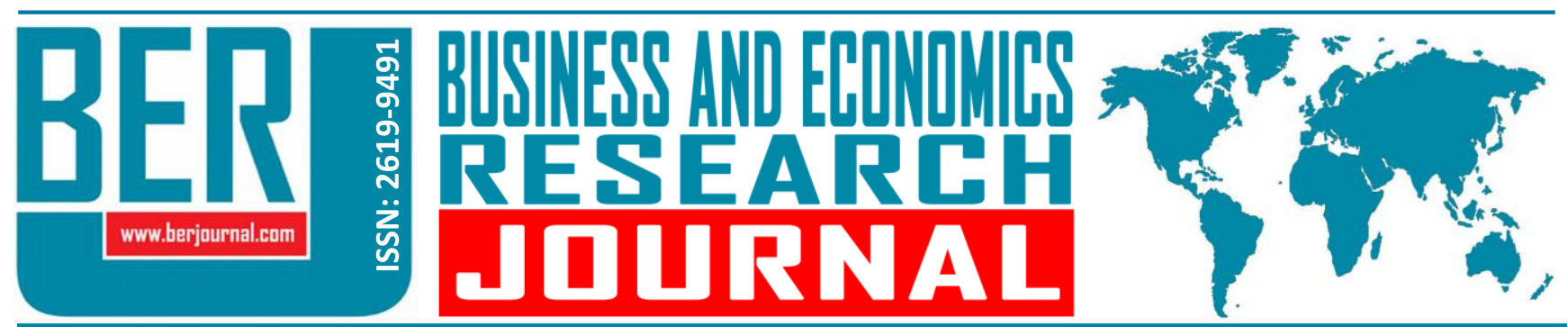

Business and Economics Research Journal Vol. 10, No. 5, 2019, pp. 1029-1038 doi: 10.20409/berj.2019.219

\title{
Middle-Income Trap: The Case of Poland
}

\section{Bozena Leven $^{\text {a }}$}

Abstract: The middle-income trap (MIT) describes systemic growth obstacles shared by various countries that occur typically at the middle-income level of their development. The following analysis relies on Rostow's classification of the stages of economic development. We focus on Rostow stages three and four, where moving from labor intensive, import and foreign direct investment (FDI) driven growth to reliance on high value-added output and exports with embedded high content of capital and technology can render sustainable long-term growth problematic. To examine MIT we study Poland, which has relied on relatively low labor costs, imported technologies, funding from the European Union and FDI to attain middle-income status. A recent slowing in Poland's growth may signal that it has exhausted some of these growth factors and is more vulnerable to MIT. To assess this vulnerability, we analyze changes in Poland's factor productivity, investment patterns, FDI, labor force educational attainments, new technology/product development, imports, export diversification, product complexity, and other factors. We conclude that certain conditions consistent with MIT are gaining importance in Poland and represent a challenge to its future economic growth.
Keywords: Economic Growth and Aggregate Productivity, International Factor Movements

JEL: F20, O40

\section{Introduction}

Most countries at the "middle level" of their development have relied on similar engines of growth: such as foreign savings and investment, relatively low labor costs, high value added imports, including technology, and FDI, along with exports based on relatively low domestic labor costs and use foreign technology and/or capital. In most cases, human capital growth in those countries lag behind wages, making them less attractive as manufacturing and investment sites over time. Consequently, for this model of development is often unsustainable in the long- term.

Determining that a country is in the middle income trap (MIT) is not solely a function of a particular GNP or per capita income; rather, it is a way to understand the phases of an economic development. While, typically, such countries GDP/capita is in between $\$ 10,000$ and $\$ 20,000$ US dollars, it is the characteristics of their economies that make them susceptible to MIT. While the definition of MIT varies in the literature, most scholars focus on declining factor productivity resulting from the exhaustion of labor intensive, import and foreign direct investment (FDI) based strategies when middle-income status is achieved. Our MIT analysis employs the general characteristics of five different stages of economic development set forth by Rostow (1959). Within that framework, the MIT typically occurs between stages III and IV, or early in the IVth stage of economic development.

This paper examines the threat of MIT in Poland, which in terms of development is now straddling between stages III and IV within the Rostow framework. In the past two decades, Poland has experienced 
steady economic growth based largely on imported technologies, relatively low labor costs and generous EU structural funds and subsidies. Recently, that economic growth has slowed, prompting economists to ask whether Poland is experiencing a MIT. To answer this question, we analyze changes in factor productivity, investment - specifically its growth and composition, FDI, educational attainments of the labor force, development of new technologies and products, the role of imports, diversification of exports and product complexity. We also examine the development of Poland's modern infrastructure, institutions (including legal environment) and demographic changes that support growth.

Our analysis yields mixed results. Several factors consistent with the MIT suggest that Poland's future growth may be unsustainable in the long run. Those factors include low and declining private investment combined with heavy reliance on EU funded investment, relatively low R\&D spending, a recently lowered retirement age (with an aging population), worsening dependency ratios, and continued dependency on FDI for technology and exports. At the same time, though, Poland's total factor and labor productivities have continued rising (though at a slow uneven rate) as the composition of exports is changing and includes more advanced value added. Consequently, we conclude that, on balance, while a number of factors that indicate a MIT are presently absent in Poland, several potentially problematic areas are plainly present that, if left unaddressed, may well hamper Poland's economic growth and development in the future.

\section{Controversy over MIT in the Literature}

The middle-income trap concept is relatively new and has often been applied to countries that have experienced rapid growth to quickly reach middle-income status, but then failed to excel (Glawe, 2016). It was first analyzed at length by the World Bank in the context of selected Asian economy slowdowns and their macroeconomic conversion problems (Gill \& Kharas, 2007). Since then, a substantial body of literature has emerged on the parameters and causes of the MIT, along with policies that may prevent its occurrence. Attempts to define the MIT, include works by Gill and Kharas, 2007; Ohno, 2009; Kharas \& Kohli, 2011. These authors concentrate on the necessary political and institutional adjustments and absent structural and institutional reforms responsible for economic slowdown. More generally, MIT is typically defined as a prolonged and systemic slowdown that prevents a country from achieving the high-income status of the most developed economies.

More specifically, the literature consistently points to declining factor productivity as a cause and characteristic of the MIT (Martin, 2017). Other contributing factors include: slow growth and the composition of investment (particularly where previous high and unsustainable government or foreign investment rates are not supported by domestic savings) (Hayat, 2014); heavy reliance on FDI to fund exports; lagging educational attainments of the labor force (Leibfritz \& Roeger, 2008); a failure to develop new technologies and products; overreliance on imports of capital and technology intensive goods (Mishal \& Abulaila, 2007); insufficient R\&D; a lack of export diversification; and limited product complexity. In addition, the slow development of modern infrastructure, weak institutions (including the legal environment), and unfavorable demographics are cited as potential factors hampering sustainable development and growth (North, 1989).

The key difference between MIT and other economic slowdowns is that these systemic causes are linked to a maturing economy, which - unless addressed - can persist for decades. In fact, the MIT is therefore often referred to as a self-reinforcing mechanism that affected economies find difficult to break (Azariadis \& Stachurski, 2005; Matsuyama, 2008).

It is worth noting that the notion of a 'trap' is derived from Nelson's "low-level equilibrium trap", which was originally applied to diverse low-income countries unable to accelerate their growth (1956). The actual income levels at which the trap occurs, the specific decline in growth rates, as well as the time involved in a MIT are not well-defined in the literature (Griffith, 2011). There is a broad agreement, however, that a MIT presupposes that the subject country's per capita income levels are in the 'teens' of thousands of dollars (Eichengreen, 2011).

Discrepancies in the precise definitions and numerical parameters that characterize a MIT are further exacerbated by the diverse range of structural characteristics and changes among the countries potentially 
threatened by it (Radwan, 2014). Indeed, it is easier to identify countries that do not face an MIT threat (e.g., countries that either insufficiently, or already developed for MIT to exist) than those that are at risk of MIT. Economies that are insufficiently developed to be at MIT risk include those exhibiting growth which relies on low-skill labor intensive production, natural resources, foreign capital supplementing low domestic savings and low diversification of exports (Baumol, 1967). Fully developed economies not at MIT risk include those with an accumulated stock of physical and human capital, high and rising total factor productivity and highskill labor and capital-intensive production that originate from own technologies and innovation. They also exhibit a per capita income exceeding $\$ 20,000$ (Gill \& Kharas, 2007; Yusuf \& Nabeshima, 2009; Woo \& Heo, 2009; Jankowska, Nagengast, \& Perea, 2012).

In between insufficiently developed and developed economies are multiple countries that could be at risk for a MIT (Rostow, 1990). For example, Brazil - which experienced strong growth from the 1950s through the 1970s - is now stuck at income levels attained in the early 1980s, and is experiencing slow productivity growth, limited export diversification and weak or declining institutional progress, as indicated by its Gini coefficient, governance and corruption indices (World Bank Annual Report, 2015). The post-2009 slowdown in Chinese growth has also fostered research on whether China is likely to experience its own MIT, and on factors that might contribute to it (Zhan, 2013).

These two countries face very different circumstances, benchmarks, and growth metrics. The utility of the MIT is that it provides a framework to assess challenges faced by widely differing countries at their third stage of development. That framework is not based on country-specific (and therefore nontransferable) empirical evidence. Rather, it pulls together broadly understood characteristics that have generally been observed as posing inherent difficulties for countries in which existing conditions that previously propelled economic growth can no longer do so.

Table 1. Major Stages of Economic Growth and Development

\begin{tabular}{|c|c|c|c|c|}
\hline $\begin{array}{l}\text { I. Reliance on } \\
\text { subsistence } \\
\text { agriculture, aid } \\
\text { dependency }\end{array}$ & $\begin{array}{l}\text { II. Introduction of } \\
\text { simple } \\
\text { manufacturing } \\
\text { involving foreign } \\
\text { capital }\end{array}$ & $\begin{array}{l}\text { III. Complex } \\
\text { manufacturing/continued } \\
\text { reliance on foreign } \\
\text { capital }\end{array}$ & $\begin{array}{l}\text { IV. Rapid } \\
\text { absorption of } \\
\text { foreign } \\
\text { management and } \\
\text { technology; } \\
\text { starting to produce } \\
\text { and develop own } \\
\text { goods }\end{array}$ & $\begin{array}{l}\text { V. Reliance on own } \\
\text { innovation, product } \\
\text { design; global } \\
\text { leader in multiple } \\
\text { products }\end{array}$ \\
\hline $\begin{array}{l}\text { 1. Low per capita } \\
\text { income growth } \\
\text { 2. Agricultural } \\
\text { employment } \\
\text { exceeding } 80 \\
\text { percent } \\
\text { 3. Government } \\
\text { driven } \\
\text { industrialization, } \\
\text { wide use of } \\
\text { subsidies } \\
\text { 4. Limited } \\
\text { structural change }\end{array}$ & $\begin{array}{l}\text { 1. Moderate per } \\
\text { capita income } \\
\text { growth } \\
\text { 2. Moderate } \\
\text { structural change } \\
\text { 3. Increased share } \\
\text { of non-agricultural } \\
\text { labor } \\
\text { 4. Progressive } \\
\text { infrastructure } \\
\text { development }\end{array}$ & $\begin{array}{l}\text { 1. Rising per capita } \\
\text { income growth } \\
\text { 2. Moderate structural } \\
\text { change } \\
\text { 3. Further increased } \\
\text { share of non-agricultural } \\
\text { labor } \\
\text { 4. Formation of a } \\
\text { domestic service industry } \\
\text { (outside of traditional } \\
\text { services) }\end{array}$ & $\begin{array}{l}\text { 1. Rapid structural } \\
\text { change } \\
\text { 2. Decisivie shift of } \\
\text { employment shares } \\
\text { from agriculture to } \\
\text { industry and } \\
\text { services } \\
\text { 3. Increased labor } \\
\text { productivity and } \\
\text { participation }\end{array}$ & $\begin{array}{l}\text { 1. Steadily } \\
\text { increased TFP } \\
\text { growth } \\
\text { 2. High capital and } \\
\text { technology content } \\
\text { of production and } \\
\text { exports }\end{array}$ \\
\hline Rwanda, Ghana & Vietnam & Thailand, Malaysia & Korea, Taiwan & $\begin{array}{l}\text { US, Japan, most of } \\
\text { the EU }\end{array}$ \\
\hline
\end{tabular}

Source: Based on Rostow's Stages of Economic Growth (1959). 
Table 1 compares certain characteristics and capabilities of the various stages of a country's economic development. At stage $\mathrm{I}$, an economy can generate growth by specializing in agricultural production and labor-intensive, low-wage products, and by importing or imitating technologies from more advanced countries. Over time, a shift from stage I to II of economic development is associated with a reallocation of capital and the workforce from the agricultural sector to the more productive industry and/or service sectors. This shift is often supported by foreign capital inflows and active government policies of industrialization. With appropriate institutional adjustments and policies, capital inflows, increased savings and productivity, countries are well-positioned to move to stage III. It is in late stage III and early stage IV, where growth must shift from (1) existing comparative advantages primarily concentrated in natural resources and/or unskilled and semiskilled labor to (2) increasing total factor productivity and developing new technologies and innovation based growth engines that the MIT risk is greatest (Porter, 2002).

\section{Potential Factors Leading to the MIT - The Case Study of Poland}

As previously noted, a reason underlying the MIT is the changing role of factors that support growth in low-income countries that have reached middle-income status. More specifically, reliance on labor intensive processes, imported technologies and foreign investment becomes less viable as growth pushes domestic prices and wages upward. It then becomes necessary to increase the productivity of labor and/or capital, facilitate rising total factor productivity, develop new technologies and innovate.

Based on Table 1, Poland should be classified at late stage III or early stage IV of its economic development, which makes it potentially susceptible to a MIT. In this section we consider selected economic characteristics listed in Table 2 that are present in Poland as that might contribute to an MIT.

Poland experienced continuous growth in the 2001-2016 period, albeit at varying rates. However, the sustainability of this growth is a recent topic of debate in the academic literature (Radwan, 2014; Pruchnik \& Toborowicz, 2014). One reason for questioning the sustainability of Poland's growth are its unique economic characteristics. Following its transition to a market economy in the 1990s, Poland was the only country able to maintain positive growth rates during the global recession and financial crisis.

Table 2. Changes in Poland's Major Indicators 1999-2016

\begin{tabular}{|c|c|c|c|c|c|c|c|c|c|c|c|c|c|c|c|c|}
\hline jear & 2001 & 2002 & 2003 & 2004 & 2005 & 2006 & 2007 & 2008 & 2009 & 2010 & 2011 & 2012 & 2013 & 2014 & 2015 & 2016 \\
\hline 1 & 1.2 & 1.3 & 3.7 & 5.6 & 3.4 & 5.8 & 6.6 & 4.8 & 1.7 & 3.8 & 4.4 & 2 & 1.3 & 3.3 & 3.7 & 3.1 \\
\hline 2 & 14.4 & 15.7 & 16.5 & 17.8 & 18.1 & 19.1 & 20.3 & 21.4 & 22.7 & 22.5 & 27.5 & 28.8 & 29.9 & 30.4 & 31.2 & 32.0 \\
\hline 3 & 90.5 & 82.1 & 83.5 & 87.5 & 94.2 & 108 & 126 & 138 & 149 & 154 & 168 & 164 & 156 & 166 & 173 & 175 \\
\hline 4 & 101 & 103 & 106 & 112 & 116 & 123 & 132 & 138 & 142 & 147 & 154 & 157 & 160 & 165 & 171 & 176 \\
\hline 5 & 103 & 108 & 123 & 129 & 142 & 164 & 181 & 193 & 182 & 206 & 222 & 232 & 246 & 263 & 283 & 308 \\
\hline 6 & 20.6 & 18.4 & 18.8 & 20.2 & 19.2 & 21.7 & 25.2 & 24.6 & 20.6 & 21.3 & 22.4 & 21.0 & 19.0 & 20.4 & 205 & 19.6 \\
\hline 7 & 1.1 & 1.3 & 1.4 & 1.5 & 1.6 & 1.9 & 2.0 & 2.0 & 2.0 & 2.2 & 2.5 & 2.5 & 2.5 & 2.5 & 2.7 & 2.6 \\
\hline 8 & 0.62 & 0.56 & 0.54 & 0.55 & 0.56 & 0.55 & 0.56 & 0.60 & 0.66 & 0.72 & 0.75 & 0.88 & 0.97 & 0.94 & 1.00 & \\
\hline 9 & 22.3 & 21.8 & 16.1 & 20.4 & 27.6 & 29.4 & 41.3 & 38.0 & 40.3 & 36.0 & 51.6 & 48.0 & 60.8 & 64.7 & 62.5 & 66.7 \\
\hline 10 & 61.5 & 62.2 & 62.9 & 63.4 & 64.0 & 64.2 & 64.4 & 64.5 & 64.5 & 64.4 & 64.2 & 63.9 & 63.4 & 63.0 & 62.4 & 61.9 \\
\hline 11 & 73.4 & 77.4 & 80.9 & 84.0 & 85.4 & 87.8 & 90.1 & 90.8 & 93.7 & 100 & 105 & 107 & 108 & 112 & 113 & \\
\hline 12 & 5283 & 3991 & 2897 & 2750 & 2223 & 4027 & 2689 & 6696 & 3799 & 3181 & 2424 & & & 9900 & 12200 & \\
\hline
\end{tabular}

Sources: Own calculations based on CIA Country Factbook, OECD Statistics and Rocznik Statystyczny GUS, Wskazniki Makroekonomiczne

The presented Indicators are as follows: (1) growth: percentage growth rate of GDP, (2) total factor productivity per hour in dollars, (3) investment index, year 2000=100, (4) value added index, year 2000=100, (5) exports index, year 2000=100,

(6) share of investment in GDP, (7) number of graduates with tertiary degrees outside of arts and sciences per 1000, (8) share of Research \& Development in GDP, (9) number of patents/1000, (10) percent of population age 18-64, (11) GDP per hour worked index, year 2000=100, (12) total FDI in million Euros.

Table 2 presents changes in the primary growth indicators that are generally considered to be relevant to a MIT. As applied to Poland, these indicators are mixed. While Poland's average growth rate from 2001 to 2008 was a relatively high 4.1 percent, it declined to an average of 2.9 percent during the 2009 to 
2016 period. This eight-year period (2009 to 2016) is too short to reveal definite trends and Poland's economic slowdown (particularly considering the global recession) and does not necessarily imply systemic threats. Nevertheless, the slowdown does coincide with the emergence of several systemic factors that may contribute to a MIT. We therefore examine changes in those economic factors to ascertain whether they tend to indicate a potential threat of a MIT for Poland.

A key factor that may prompt the MIT is a slowdown or decline in factor productivity. Though estimates of total factor productivity rely on numerous assumptions and are often problematic, productivity trends are frequently used to assess an economy's strengths (Felipe, 1999; Van Biesebroeck, 2007). In the literature, common diverse results obtained when measuring productivity are frequently attributed to differences in the methodologies employed (Syverson, 2011). It is widely accepted that measuring factor productivity as aggregate numbers often hide subtle changes in labor and capital markets. Thus, reliance on productivity cross sectional data for different economies tends to provide a less accurate picture of the situation on the ground, while time series data for a single country using a consistent methodology can sometimes more accurately reveal economic progress.

Typically, prices of factors of production rise as growth continues, often depressing their productivity. For Poland, apart from 2010, total factor productivity per hour measured in dollars per hour rose steadily, though at an uneven rate. A similar pattern is observed in the growth of GDP values in dollars per hour worked, which is often considered a proxy for labor productivity. With all the potential flaws associated with the aggregate indicators, this observed growth does indicate that Poland avoided a major productivity decline even in the wake of the global recession. At the same time, investment and value-added also increased steadily and at comparable rates, corroborating reliance on factor productivity growth as an indicator of Poland's economic strength. In combination, these two factors suggest that the MIT is less likely despite the slowdown in Poland's economic growth.

Figure 1. Poland's Total Factor Productivity Index US=1 (Current Purchasing Power Parities)

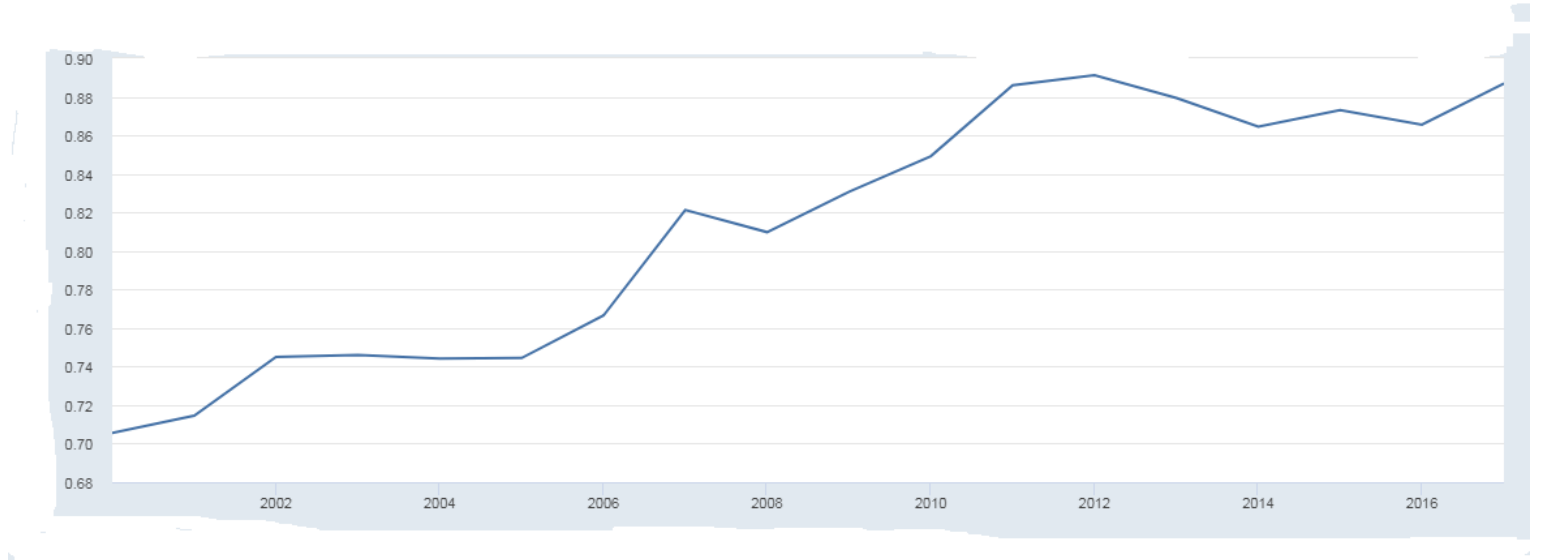

Source: Economic Research - FED of St Louis 2017.

However, when measured against other countries (US) Poland's total factor productivity Index is inconclusive. After an initial rise (2001 - 2007), it leveled off during the 2011-2017 period, as illustrated in Figure 1.

A more mixed picture emerges from our analysis of changes in investment in Poland. Where private investment predominates, this indicator tends to be the most volatile component of GDP, as it quickly responds to cyclical fluctuations. In Poland, this volatility is likewise observable, but for a different reason. Specifically, the rate of investment using public funds is approximately three times higher than private fund investment and is accelerating (Fixed Assets in the National Economy in 2013). In the period of 2008 to 2014, 
the share of public investment rose by 10 percentage points and the share of private investment declined by roughly 15 percentage points, indicating a limited domestic savings.

The high and rising share of public investment results from Poland's reliance on EU funding, which has focused on large capital-intensive projects such as infrastructure (highways), environmentally friendly transport systems (railways, public transport), broadband internet access related initiatives, and the development of renewable energy sources. In terms of flow, EU funding is usually transferred to various levels of government responsible for infrastructure and is classified as public investment. Throughout most of the 2008 to 2015 period, Poland was among the three largest recipients of EU funds (and the top recipient in 2013), and received over $\$ 20$ billion in funding for domestic investment. However, the absorption of those funds has been problematic, threatening future inflows and - in some quarters - cited as a factor in recent EU funding cuts (Szymański, 2017). Indeed, Poland's growth rates lag a steady rise in EU funded public investment.

The relatively short time period examined and major global macroeconomic decline occurring during that time period do not permit firm conclusions whether future investment growth rates will, or will not, move Poland closer to the MIT. However, as noted above, the bulk of EU funding in Poland is earmarked for developing the infrastructure needed to support sustained growth. Even though modern infrastructure typically relies largely on public funding, the composition of investment is a cause for concern, and possibly, of consequence, because the lack of new private investment competing with, and possibly substituting for, public investment (e.g., EU funded capital) speaks to growth sustainability. Further analysis of trends and factors affecting the low and declining share of private investment is needed to assess whether investment composition and its changes are likely to contribute to a systemic slowdown.

Another potential contributor to the MIT is rooted in human capital and education (Jimenez, 2012), particularly when the human capital growth needed to produce high-skill innovations lags behind wages (Zhang et al., 2013). Using tertiary education as a proxy for human capital attainment, the data indicates that Poland has been making steady progress in this area. The number of tertiary degree holders outside of arts and sciences, increased 2.6-fold between 2001 and 2016. Poland's overall share of population with tertiary degrees - which was 28 percent in 2015 - also compares favorably with other OECD countries. It is on par with Germany, and exceeds those of Hungary, Portugal, Italy and the Czech Republic (OECD Statistics). While it is possible that new graduate degree holders' skills may not match labor market demand, the rapid growth in the overall numbers of educated Polish workers tends to diminish the threat of a MIT.

High education attainments do not, however, appear to have translated into high levels of innovation. While measuring the role of innovation in growth is often problematic, the use of three indicators estimating internal progress in this area, as well as the relative positioning of Poland the country vis-a-vis several other economies, is a plausible basis for making general observations.

One such indicator is the average value of Innovation Index for Poland in the period 2000-2017 (Cornell, 2019), which was 40.4 points with a minimum of 38 points in 2011 and a maximum of 42 points in 2017. These values place Poland behind several countries in the region with lower GDP per capita, such as Bulgaria, Slovakia, Slovenia and Hungry. Two additional indicators previously were presented in Table 2: that is, the share of Research and Development (R\&D) in GDP and the number of patents granted per 1,000 people. Both support the inference that innovation is not driving Poland's growth (Sutz, 2012).

Specifically, although Poland's GDP share of spending on R\&D increased throughout the examined period, it was the lowest among Europe's OECD countries, at around 1 percent of GDP. The equivalent numbers for Germany, Hungary, Portugal, Italy and Czech Republic were substantially higher - at 2.9, 1.4, $1.3,1.3$ and 2 percent of GDP, respectively.

Similarly, while the number of patents granted per 1000 people - increased in Poland from 22.5 to 66.7 in the 2000 to 2016 period, the World Intellectual Property Organization ranks Poland $20^{\text {th }}$ in filings for intellectual property protection rights, which is behind most European countries at a similar level of 
development (Khan, 2016). This low number of patent applications is consistent with Poland's low spending on R\&D and may reflect, at least in part, limited government support for private innovation.

In summary, these limited data do not indicate that Poland is aggressively investing in or otherwise fostering home grown innovation. Instead, most firms likely rely on newer imported technologies and capital to combat diminishing comparative advantages in labor.

Regarding human capital, two factors that can contribute to economic stagnation and, potentially MIT, are an aging labor force and rising dependence on those still working to fund social safety nets. In Poland these factors are not yet fully in play. The share of Poland's working age population remained over 60 percent throughout the examined period, peaking in 2008-2009 and declining slightly afterwards. Relatedly, the labor participation rate followed an inverse trend - peaking at 57 percent in 1999 and falling to 53 percent in 2007, before recovering to 56.3 percent in 2016 - and does not appear to raise MIT concerns (Poland Labor Force Participation Rate 1998-2017, Trading Economics). Another popular human capital measure is the dependency rate, which reveals the number of dependents aged up to 16 and over 65 as a percentage of the total population. Poland's dependency rate is 43.8 percent, which is lower than those of Germany (51.62 percent), the Czech Republic (49.52 percent) and Hungary (47.91 percent), indicating that a higher percentage of Polish labor is of working age and, therefore, less strain on the state budget (Poland Dependency Ratios, Index Muni 2017; Age Dependency Ratio, Index Muni 2016). However, this situation may be adversely impacted, over time, by the Polish government's recent decision to reduce the retirement age to below 65, which is lower than the retirement age in most EU countries. At this juncture the available data (which are quite limited) do not support a hypothesis that Poland's demographics presently constitute a systemic threat to economic growth.

Exports - and their structure - are another major engine of sustainable economic growth. In particular, countries that seek to progress from stage III of their economic development need to move away from labor intensive exports and/or exports relying on FDI and imported technology to capital and technology intensive products based on domestic innovation. Between 2000 and 2016 Poland's exports tripled and experienced some structural change. In 2004 machinery and equipment (21.9 percent) dominated Polish exports, followed by metals and semi-finished metal products ( 12.57 percent), minerals (5.73 percent), plastics and rubber products ( 5.14 percent), chemicals ( 5.06 percent), textiles ( 4.9 percent), food and tobacco products (3.73 percent), and wood and paper products (3.21 percent) (Exports/Imports by Sections CN/SITC/CPA/BEC and Groups of Countries 2017). By 2016, the following shifts had occurred, by percentage of total exports: machinery including computers, (13.1 percent of total exports), vehicles (12.2 percent), electrical machinery and equipment (11.5 percent), furniture ( 6 percent), plastics ( 4.7 percent), articles of iron or steel ( 3 percent), mineral fuels including oil ( 2.6 percent) and meat ( 2.2 percent) (Workman, 2017).

It is difficult to determine from these highly aggregated categories the extent of value added generated by skilled labor or technology in those exports, which is necessary in the long run to avoid a MIT. However, some structural changes in Poland's export composition are worth noting: in 2016, the largest export categories included computers and vehicles, which were absent in 2004. This itself does not necessarily signal a higher innovation content in Polish exports; in fact, EU firms frequently rely on less expensive Polish labor to produce their vehicles and other machinery in Poland. There are, however, some indications that Polish exports have become more advanced and do contain a higher value added. For example, metals and semi-finished metal products, minerals, and textiles (all of which are typically low valueadded exports) were no longer ranked among Poland's top ten export categories in 2016, having been replaced by a higher share of equipment and machinery (which are more sophisticated exports). At the same time, overall Polish domestic value added export content as a share of total export value actually declined between 2005 and 2016, from 75.32 percent to 73.10 (OECD, 2016), indicating that the current export mix still heavily relies on foreign capital and technology and use of less expensive Polish labor. Accordingly, the shift from textiles, minerals and food products to more technology-based exports does not necessarily protect Poland from a MIT. 
Further examination of Poland's FDI structure sheds only limited light onto the extent of modernization and reliance on domestic versus foreign innovation in Polish production (Woo \& Heo, 2009). When comparing changes in the accumulated stock of FDI in Poland between 2005 and 2015, we see that the total share of inward flowing FDI in Poland's GDP increased from 24 percent to 40 percent (OECD, 2016). Throughout the entire period manufacturing, transportation equipment, and food processing were the most attractive locations for foreign capital. By 2015 however, services - whose development is necessary to facilitate modern growth - gained a larger share in FDI, particularly through financial intermediaries (19 percent) and commerce (16 percent) but also a slight increase in manufacturing. Like its changing export structure, Poland's changing FDI composition (and increased reliance on it) indicates that the Polish economy has not quite moved to economic stage IV of development. In fact, these aggregated numbers describing the composition and value added of exports and FDI indicate that Poland increased its dependence on foreign capital. This latter finding is inconsistent with moving to a more mature stage of economic development.

\section{Policy Considerations}

Fundamentally, the question that our MIT analysis addresses - at least in part - is whether the engines of Poland's rapid growth and development in the last two decades will support that country's further transformation into a modern sustainable economy. From that analysis, we see that Poland - roughly at end stage III in its economic development - is juxtaposed between two outcomes; continued growth or creeping stagnation. On the positive side, several of the factors examined indicate a lack of certain systemic threats commonly associated with a MIT. Of those factors, the most noteworthy is Poland's productivity growth, as measured by total factor productivity and GDP growth per hour, which does not reveal any signs of a major slowdown. Another is education - as a rapid increase in the share of those with tertiary degrees is decidedly pro-growth. Regarding demographics, both the dependency ratio and data on aging may also be broadly understood as supporting the transformative growth that Poland needs to avoid a MIT, though this may be altered by the recent lowering of pension/retirement eligibility ages.

Several other factors, however, suggest that Poland can do more to increase the prospects for sustainable growth. For example, the high and rising share of public investment financed through EU infrastructure funds has played a key role in Poland's successes to date. Unsurprisingly, the continued flow of such investment remains a vital component of future economic growth. To facilitate that flow, Poland needs to address the frequent (and arguably justified) criticism from Brussels about its limited ability to absorb funds (Kersan- Škabić \& Tijanić, 2017). Some changes that have been suggested to increase this absorption include modifying Poland's relevant institutional and regulatory framework, simplifying public procurement rules, eliminating the need for a ministerial-level approval of all documented requirements, limiting the recourse of unsuccessful bidders to the courts concerning low Euro (i.e., under 100,000 Euros) projects, and simplifying the refund claims process to the EU for refunds that successful bidders are entitled to after a project is completed.

Poland also needs to increase the share of private investment. This may require more businessfriendly regulation, streamlining business registration procedures, and carefully monitoring the impact of the recent reform of the insolvency law. In addition, restrictive labor laws and irregular work relationships often hamper small and medium-size business investment and growth, undermine labor productivity, and hinder firms from hiring new workers (OECD, 2016).

Another factor that can be expected to increase the MIT threat over time are recent changes in Poland's retirement age, which was lowered to 60 for women and 65 for men (reversing an increase in retirement to 67 for both men and women that was approved in 2012 by the former government). While it is too early to statistically assess the impact of this policy change, one consequence will certainly be to negatively impact Poland's future dependency ratios and, potentially, growth, as the number of retirees increases (most of whom rely exclusively on their state pensions).

The role of innovation in Poland's economy is a third area of concern. Poland's relatively low current R\&D spending indicates limited government support in that area. This situation differentiates Poland from other countries at a similar development stage, where government-funded R\&D provided critical support 
(e.g., the U.S., Japan, Korea, and Taiwan), particularly in areas where high costs and high risks were required to produce disruptive technological advances.

And, while changes in Poland's foreign trade structure indicate a shift from manufacturing low valueadded exports to more advanced products, both exports and FDI still rely on relatively lower labor costs to produce goods based on imported technologies. This implies that a shift to growth in Poland based on domestic technologies and innovation has yet to occur.

\section{Conclusions}

The existence of the MIT and the systemic factors that contribute to it are still debated in the literature. However, middle income countries that rely too heavily on high value added imports, including technology and FDI as major growth drivers, and primarily export goods and services that rely on foreign technology and/or capital, can be vulnerable to slowing or even stagnant growth. In this paper we have assessed several factors that are typically present when approaching the point of economic "switch" generally described by the MIT, using the case study of Poland. Our analysis yields mixed results. While several factors that tend to signal a MIT are presently absent in Poland, several potentially problematic areas are plainly present. These problematic areas include the low share and slow growth of private investment, suboptimal absorption of EU funds, stagnant, and even declining value added of exports, limited government spending on R\&D, and an expected rise in dependency rates. If left unaddressed, those factors, alone and in combination may well hamper Poland's economic growth and development in the future.

\section{References}

"Age Dependency Ratio", (2016). IndexMundi - Country Facts retrieved from www.indexmundi.com/facts/indicators/SP.POP.DPND/compare?country=de\#country=cz:de:hu:pl

Ancyparowicz, G. (2009). The impact of direct foreign investments on the growth of the Polish economy in the postaccession period. Central Statistical Office of Poland: Information Portal. GŁÓWNY URZĄD STATYSTYCZNY, Departament Statystyki Finansów. Retrieved from stat.gov.pl/cps/rde/xbcr/gus/pgw_wplyw_bezp_inwest_zagr_na_wzrost_pol_gosp.pdf

Azariadis, C., \& Stachurski, J. (2005). Poverty traps. In: Durlauf, SN and Aghion, P. (Eds). Handbook of Economic Growth, Chapter 5. Elsevier: Amsterdam.

Baumol, W. (1967). Macroeconomics of unbalanced growth: The anatomy of urban crisis. The American Economic Review, 57(3), 415-426.

Cornell University, (2019). Global Innovation Index 2019. S.C. Johnson School of Business, Ithaca, NY.

Eichengreen, B. (2011). Escaping the middle-income trap. Proceedings - Economic Policy Symposium - Jackson Hole, 409-19. Federal Reserve Bank of Kansas City.

Exports/Imports by Sections CN/SITC/CPA/BEC and Groups of Countries, (2017). Analyses and Decisions Support System (SWAiD). Central Statistical Office of Poland. Retrieved from http://swaid.stat.gov.pl/EN/HandelZagraniczny_dashboards/Raporty_predefiniowane/RAP_SWAID_HZ_3_12.a spx

Felipe, J. (1999). Total factor productivity growth in East Asia: A critical survey. Journal of Development Studies, 35(4), 1-41.

Fixed Assets in the National Economy in 2013, (2014). Poland. Central Statistical Office. Central Statistical Office \& National Accounts Department, 29 December.

Glawe, L., \& Wagner, H. (2016). The middle-income trap: Definitions, theories and countries concerned-A literature survey. Comparative Economic Studies, 58, 507-538.

Gill, I., \& Kharas, H. (2007). An East Asian renaissance: Ideas for economic growth. Washington, DC: World Bank.

Griffith, B. (2011). Middle-income trap. Frontiers in development policy: A primer on emerging issues. Ed. Raj Nallari, Shahid Yusuf, Rwitwika Bhattacharya. World Bank, 39-43.

Hayat, A. (2014). FDI and economic growth: The role of natural resources. IES Working Paper 36/2014. IES FSV. Charles University. 
Jankowska, A., Nagengast, A., \& Perea, J. (2012). The product space and the middle-income trap: Comparing Asian and Latin American experiences. OECD Development Centre Working Papers, 311, OECD Publishing, Paris.

Jimenez, E. (2012). Stuck in the middle? Human capital development and economic growth in Malaysia and Thailand. Policy Research Working Paper, No. WPS 6283. Washington, DC: World Bank.

Kharas, H., \& Kohli, H. (2011). What is the middle income trap, why do countries fall into it, and how can it be avoided? Global Journal of Emerging Market Economies, 3(3), 281-289.

Kersan-Škabić, I., \& Tijanić, L. (2017) Regional absorption capacity of EU funds. Economic Research-Ekonomska Istraživanja, 30(1), 1191-1208.

Khan, M., (2016). World intellectual property indicators 2016: Economics \& Statistics Series. The Journal of World Intellectual Property, 19, 5-6.

Leibfritz, W., \& Roeger, W. (2008). The effects of aging on labor markets and economic growth. In Hamm I., Seitz H., Werding M. (Eds), Demographic Change in Germany. Berlin, Heidelberg: Springer.

Martin, F. (2017). Why does economic growth keep slowing down? On the economy blog. Federal Reserve Bank of St. Louis, 9 Feb.

Matsuyama, K. (2008). Poverty traps. In Durlauf, S.N. and Blume, L. (Eds). The New Palgrave Dictionary of Economics, 2nd ed., Basingstoke: Palgrave Macmillan.

Mishal, Z., \& Abulaila, Z. (2007). The impact of foreign direct investment and imports on economic growth: The case of Jordan. Journal of Economic and Administrative Sciences, 23, 1-31.

North, D. (1989). Institutions and economic growth: An historical introduction. World Development, 17(9), 1319-1332.

OECD Economic Surveys: Poland, (2016). OECD Economic Surveys.

OECD Statistics, (2017). OECD Statistics. OECD. Retrieved from http://stats.oecd.org/\#

Ohno, K. (2009). Avoiding the middle-income trap - Renovation industrial policy formulation in Vietnam. ASEAN Economic Bulletin, 26(1), 25-43.

Poland Dependency Ratios, (2017) IndexMundi: World Factbook. Retrieved from www.indexmundi.com/poland/dependency_ratios.html

Poland Labor Force Participation Rate 1998-2017, (2017). Trading Economics. Trading Economics, Retrieved from tradingeconomics.com/poland/labor-force-participation-rate

Porter, M. (2002). Executive summary: Competitiveness and stages of economic development. The Global Competitiveness Report 2001-2002 16(25). World Economic Forum.

Pruchnik, K., \& Toborowicz, J. (2014). Low level of innovativeness and the middle-income trap Polish Case Study. Journal of Entrepreneurship, Management and Innovation, 10(2), 141-57.

Radwan, I. (2014). Avoiding the middle-income trap in Poland. World Bank, 19 Aug.

Rostow, W. W. (1959). The stages of economic growth. The Economic History Review, 12, 1-16.

Rostow, W. W. (1990). The stages of economic growth: A Non-communist Manifesto. Cambridge University Press.

Sutz, J. (2012). Measuring innovation in developing countries: Some suggestions to achieve more accurate and useful indicators. International Journal of Technological Learning, 5, 40-57.

Syverson, C. (2011). What determines productivity? Journal of Economic Literature, 49(2), 326-65.

Szymański, D. (2017). Plan morawieckiego na razie tylko na papierze. Polska z najgorszym wynikiem od 1996 R. Business Insider Polska. Business Insider, 01 Aug.

Van Biesebroeck, J. (2007). Robustness of productivity estimates. The Journal of Industrial Economics, 55, 529-569.

Woo, J., \& Heo, U. (2009). Corruption and foreign direct investment attractiveness in Asia. Asian Politics \& Policy, 1.2, 223-38.

Workman, D. (2017). Poland's top 10 exports. World's Top Exports, 12 October.

World Bank Annual Report, (2015). Washington DC.

Yusuf, S., \& Nabeshima, K. (2009). Tiger economies under threat: A comparative analysis of Malaysia's industrial prospects and policy options. Washington, DC.

Zhang, L., Pollak, E., Darwin, R., Boswell, M., \& Rozelle, S. (2013). Are elite university graduates aiding China's transition to an innovation-based economy? Results from a career choices survey among would-be innovators in China and the USA. Asia-Pacific Journal of Accounting and Economics, 20(1), 58-69. 